\title{
INTRODUKSI TEKNOLOGI PENGOLAHAN KELAPA MENJADI COCONUT CHIPS DI UKM MAJU BERSAMA DESA KEKAIT, GUNUNG SARI, LOMBOK BARAT
}

\author{
Hary Kurniawan*, Sukmawaty, Ansar, Kurniawan Yuniarto, Rahmat Sabani, Murad \\ Program Studi Teknik Pertanian, Fakultas Teknologi Pangan dan Agroindustri \\ Universitas Mataram
}

*) Korespondensi: harykurniawan@unram.ac.id

Diterima 12 November 2020 / Disetujui 10 Desember 2020

\begin{abstract}
ABSTRAK
Salah satu kelompok usaha di Desa Kekait yang saat ini sedang berkembang yaitu Kelompok Usaha Mikro (KUM) Maju Bersama yang mengolah nira aren menjadi gula cetak dan gula semut. Desa Kekait merupakan salah satu wilayah yang banyak ditumbuhi tanaman kelapa. Namun teknologi pengolahan kelapa masih belum dilirik sebagai sebuah peluang lini produk oleh KUM Maju Bersama. Sebagai upaya dalam diversifikasi produk olahan kelapa sekaligus menambah lini produk KUM Maju Bersama, maka introduksi pengolahan kelapa perlu dilakukan. Salah satunya adalah memperkenalkan coconut chip kepada mitra sebagai salah satu alternatif produk unggulan selain gula semut dan gula cetak, sehingga meningkatkan perekonomimian anggota mitra khususnya. Tujuan dari kegiatan ini adalah meningkatkan pengetahuan dan keterampilan mitra dalam teknologi pengolahan kelapa menjadi coconut chip sebagai salah satu produk unggulan mitra. Metode yang dilakukan yaitu sosialisasi dan disertai praktek pengolahan kelapa. Berdasarkan hasil kegiatan yang telah dialakukan diperoleh bahwa mitra belum mengenal keripik kelapa. Namun setelah mengikuti rangkaian pelatihan, mitra mengetahui dengan baik manfaat dan produk olahan daging kelapa yang memiliki nilai ekonomi yang cukup tinggi. Selain itu, keterampilan mitra pun meningkat setelah melakukan praktek langsung pengolahan daging kelapa menjadi keripik kelapa. Tindak lanjut yang akan dating yaitu berupa pelatihan pengemasan dan penyimpanan keripik kelapa, serta pendampingan pengurusan PIRT agar membantu strategi pemasaran dan memperluas jangkauan pemasaran.
\end{abstract}

Kata kunci: coconut chip, Desa Kekait, Pengolahan kelapa

\section{PENDAHULUAN}

Desa Kekait yang berlokasi di Kecamatan Gunung Sari, Kabupaten Lombok Barat, NTB merupakan salah satu sentra penghasil gula semut aren dan sekaligus sebagai salah satu penopang ekonomi masyarakat setempat. Kelompok Usaha Mikro (KUM) Maju Bersama yang berlokasi di Desa Kekait, Kecamatan Gunung Sari, Lombok Barat merupakan salah satu KUM yang aktif dan masih terus berkembang hingga saat ini dengan produk utamanya adalah gula cetak dan 
gula semut serta telah memiliki rumah produksi yang cukup laik dengan ditunjang oleh alat salah satunya adalah pengering serbaguna (Kurniawan dkk., 2018).

Desa Kekait selain banyak ditumbuhi tanaman aren, juga banyak ditemukan tanaman kelapa. Kelapa sebagai tanaman yang tersebar luas khususnya di provinsi NTB, menghasilkan daging buah yang mempunyai potensi yang tinggi untuk dikembangkan sebagai bahan baku pangan bernilai tinggi. Buah kelapa yang sudah tua mengandung kalori yang tinggi, sebesar 354 kal per 100 gram, yang berasal dari minyak kurang lebih 33 persen, karbohidrat 15 persen dan protein 3 persen. Kualitas protein daging buah kelapa sangat baik, karena mempunyai skor asam amino yang tinggi, dan tidak mengandung senyawa anti nutrisi (Subagio, 2012)

Kelapa dapat dimanfaatkan menjadi berbagai macam produk yang memiliki nilai ekonomi tersendiri. Hampir setiap bagian tanaman kelapa dapat dimanfaatkan untuk memenuhi kebutuhan hidup manusia. Daging buah kelapa dapat dipakai sebagai bahan baku untuk menghasilkan kopra, minyak kelapa, coconut cream (santan) dan kelapa parutan kering (desiccated coconut), sedangkan air kelapa dapat dipakai untuk membuat cuka dan nata de coco. Tempurung dapat dimanfaatkan untuk membuat arang aktif dan kerajinan tangan. Dari batang kelapa dapat dihasilkan bahan-bahan bangunan baik untuk kerangka bangunan maupun untuk dinding serta atap. Daun kelapa dapat diambil lidinya yang dapat dipakai sebagai sapu, serta barang-barang anyaman (Abadi, 2020)

Terdapat banyak produk olahan dari kelapa, salah satu diantaranya adalah keripik kelapa atau yang lebih dikenal dengan istilah coconut chip seperti ditnjukkan pada Gambar 1. Proses pembuatan coconut chip relatif mudah dimana daging kelapa yang sudah dibersihkan dari kulit arinya dicuci bersih lalu diris tipis kemudian dikeringkan, setelah itu dikemas.

Sebagai salah satu KUM yang terus berkembang, KUM Maju Bersama perlu melakukan pengembangan usaha, salah satunya melalui lini produk yang dihasilkan. Berdasarkan uraian di atas maka perlu dilakukan introduksi pengolahan kelapa menjadi coconut chip kepada KUM Maju Bersama sebagai salah satu produk unggulan selain gula semut dan gula cetak. Hal ini perlu ditunjang dengan teknologi yang telah tersedia oleh mitra seperti mesin pengering serbaguna.

Dengan demikian pengembangan kawasan usaha agroindustri berbasis komoditas unggulan daerah merupakan bentuk pengembangan wilayah, dimana pembangunan kawasan industri yang berbasis sumberdaya daerah ini akan menciptakan iklim yang sehat, selain nilai tambah produk bahan baku yang meningkat sehingga nilai jual yang ada menjadi tinggi, juga akan membantu dalam hal penciptaan lapangan kerja bagi masyarakat (Wardanu \& Anhar, 2014)

Tujuan dari kegiatan ini adalah meningkatkan pengetahuan dan keterampilan mitra dalam teknologi pengolahan kelapa menjadi coconut chip sebagai salah satu produk unggulan mitra. 


\section{METODE KEGIATAN}

Kegiatan pengabdian pada masyarakat ini berupa introduksi teknologi pengolahan kelapa menjadi coconut chip. Metode pelaksanaannya yaitu melalui penyuluhan dan praktek pengolahan kelapa menjadi coconut chip. Adapun tahapan pelaksanaan kegiatan meliputi (1) sosialiasi dan koordinasi rencana kegiatan kepada mitra, (2) penyuluhan tentang pengolahan kelapa menjadi coconut chip, (3) praktek pengolahan kelapa menjadi coconut chip. Sementara itu evalusi kegiatan ini dilakukan secara langsung pada saat kegiatan. Pertama, evaluasi dilakukan setelah penyampaian materi dan produk yang dihasilkan.

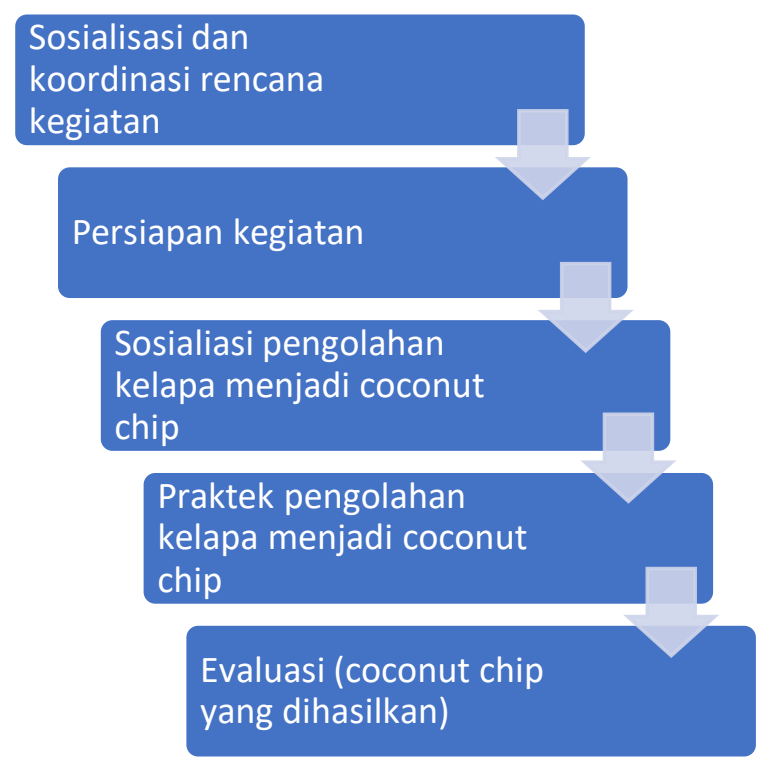

Gambar 1. Tahapan pelaksanaan kegiatan

Prosedur evaluasi meliputi kemampuan penguasaan materi dan tanggapan terhadap materi yang telah diberikan. Kedua, keterampilan peserta dalam praktek pengolahan kelapa mejadi coconut chip, dengan meninjau dari aspek produk yang dihasilkan dan aspek kebersihan serta higienitas baik dalam penanganan bahan baku maupun produk akhir. Secara umum tahapan pelaksanaan kegiatan disajikan pada Gambar 2.

\section{HASIL DAN PEMBAHASAN}

Pada kegiatan pengabdian ini, dilakukan pertemuan awal dengan kepala Dusun kekait Daye, yaitu Bapak Muhammad Yusron dan Ketua KUM Maju Bersama, Bapak Burhan. Tujuan dari pertemuan awal ini adalah untuk berkoordinasi sekaligus mensosialisasikan rencana kegiatan yang akan dilaksanakan. Hasil dari pertemuan ini yaitu masyarakat di Dusun Kekait Daye dan KUM Maju Bersama menyambut baik rencana kegiatan yang akan dilakukan oleh tim. Baik tim maupun ketua KUM Maju Bersama telah menyepakati rencana kegiatan pengabdian kepada masyarakat dan kepala dusun siap membantu mensosialisaikan kegiatan tersebut kepada warga.

\section{Persiapan pelaksanaan kegiatan}

Berbagai persiapan dilakukan
untuk merealisasikan kegiatan ini
diantaranya penyusunan materi yang
disajikan berupa handout, pembuatan
kuisioner, pembuatan leaflet, X banner
dan spanduk. Selain itu agar tujuan
kegiatan dapat tercapai dengan baik,
dilakukan pembuatan keripik kelapa yang
digunakan sebagai contoh produk yang
akan ditunjukkan kepada mitra seperti
ditunjukkan pada Gambar 2 .




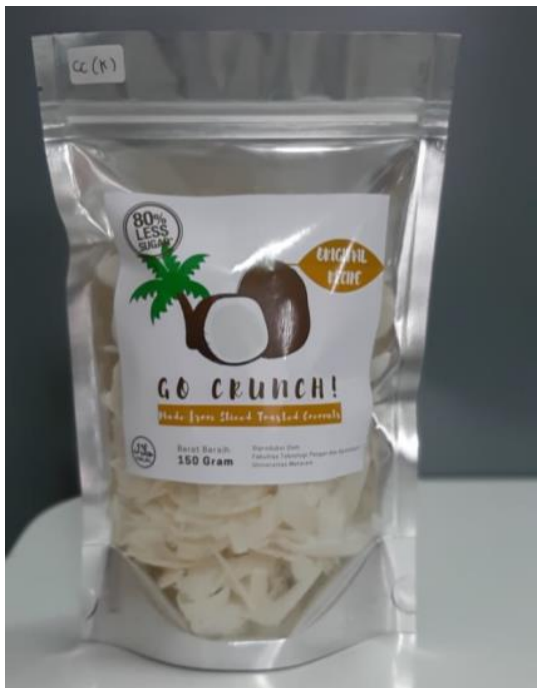

Gambar 2. Contoh produk keripik kelapa

\section{Pelaksanaan Kegiatan Pengabdian}

Kegiatan pengabdian kepada masyarakat ini dilaksanakan pada Sabtu, 25 Juli 2020 bertempat di Desa Kekait Daye, Kecamatan Gunung Sari, Kabupaten Lombok Barat. Kegiatan ini dimulai dengan sambutan oleh Bapak Muhammad Yusron selaku Kepala Dusun Kekait Daye dan didampingi oleh Bapak Burhan selaku ketua Ketua KUM Maju Bersama. Usai memberikan sambutan, kegiatan dilanjutkan dengan pembagian kuisioner kepada peserta yang hadir. Peserta diminta mengisi kuisioner sebelum diberikan materi seperti ditunjukkan pada Gambar 3. Pengisian kuisioner ini bertujuan untuk megetahui sejauh mana pemahaman mitra mengenai pengolahan daging kelapa yang selama ini telah dilakukan.

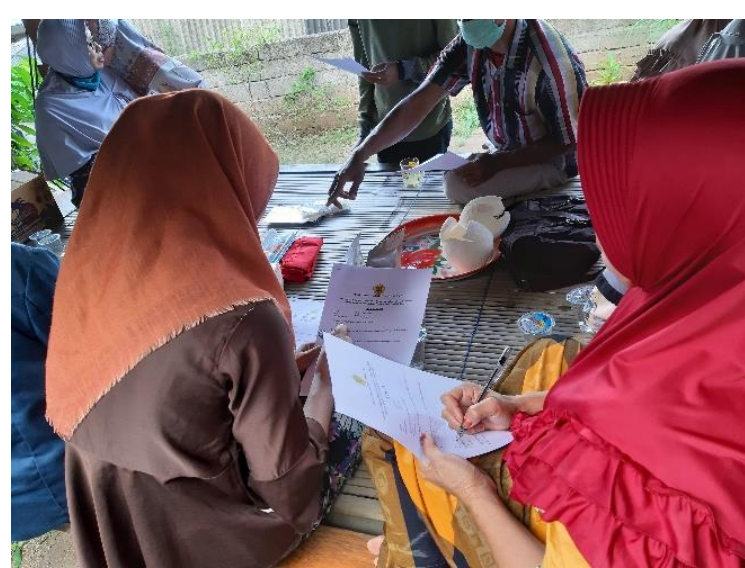

Gambar 3. Pengisian kuisioner sebelum pemberian materi

Kegiatan dilanjutkan dengan penyajian materi yang disampaikan oleh tim seperti ditunjukkan pada Gambar 4. Materi disampaikan melalui diskusi dengan bantuan handout. Pada sesi ini, peserta juga diberikan leaflet yang berisi sekilas tentang kelapa dan produk olahan kelapa. Pada sesi penyampaian materi, peserta diberikan penjelasan mengenai sekilas fakta-fakta tentang daging kelapa seperti kandungan nutrisnya maupun berbagai manfaat dari kelapa. Selain itu, peserta juga ditunjukkan berbagai produk olahan kelapa seperti VCO, santan instan, dan kelapa parut kering (desiccated coconut).

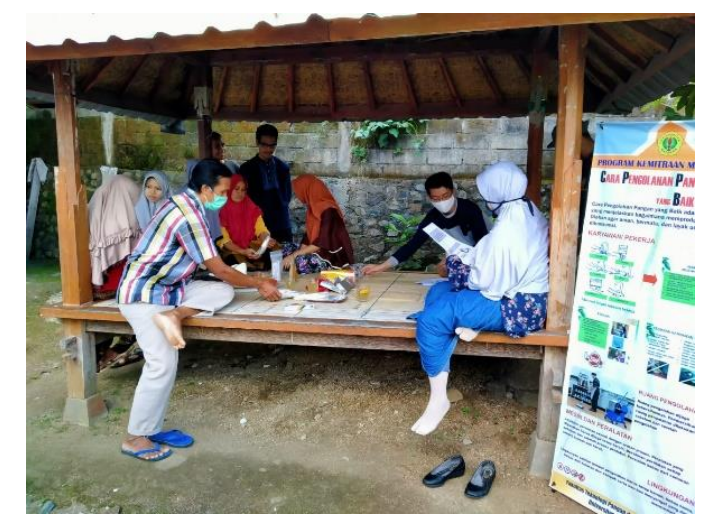

Gambar 4. Penyampaian materi oleh tim 
Setelah penyampaian materi, peserta diajak untuk praktek mengolah daging kelapa menjadi keripik kelapa dengan didampingi oleh adik-adik mahasiswa dari program studi Teknik Pertanian seperti yang disajikan pada Gambar 5. Pada sesi ini, selain peserta diberikan penjelasan mengenai pengolahan daging kelapa, peserta juga diberikan kesempatan untuk praktek mengolah daging kelapa menjadi keripik kelapa. Peserta dapat mempraktekkan dengan baik cara mengolah daging kelapa menjadi irisan kelapa tipis yang kemudian dikeringkan menggunakan alat pengering seperti yang ditunjukkan pada Gambar 6. Adapun keripik kelapa yang dihasilkan oleh mitra setelah dikeringkan menggunakan alat pengering ditunjukkan pada Gambar 7.

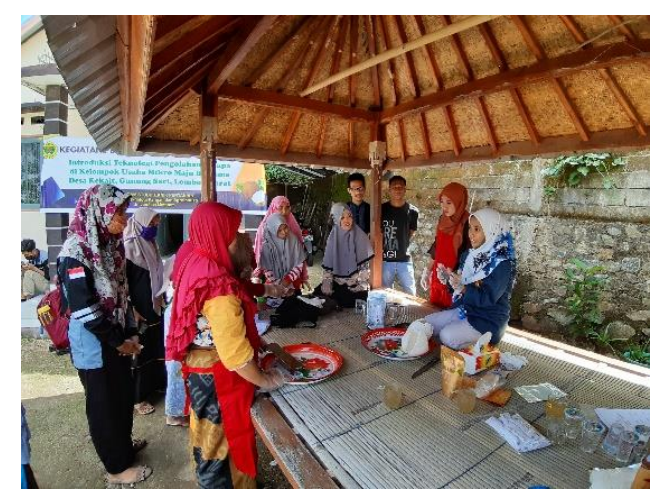

(a)

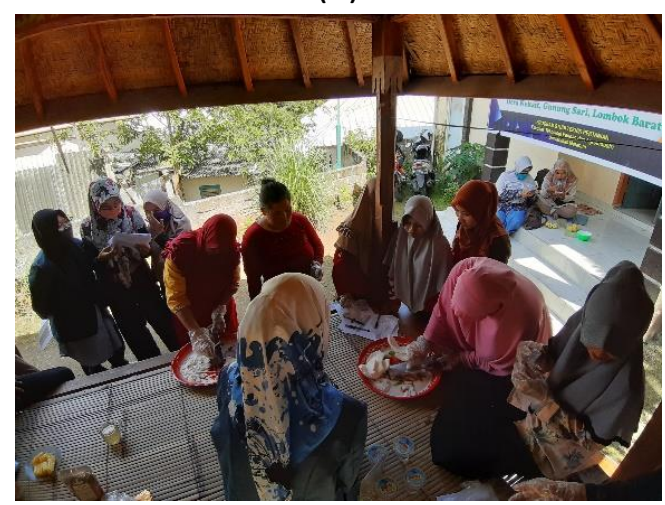

(b)
Gambar 5. (a) Penjelasan cara pengolahan keripik kelapa; (b) Pengirisan daging kelapa

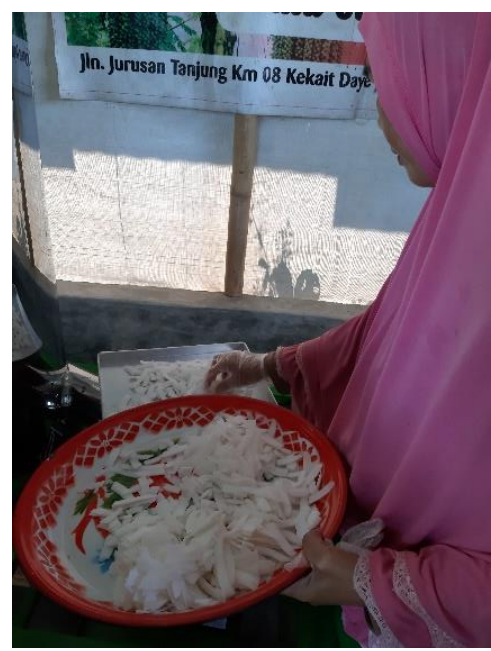

(a)

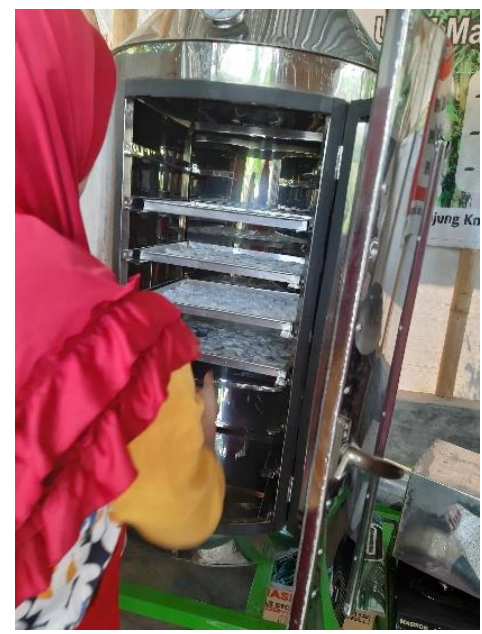

(b)

Gambar 6. (a) Daging kelapa yang telah diiris tipis dan siap dikeringkan menggunakan alat pengering; (b) Proses pengeringan

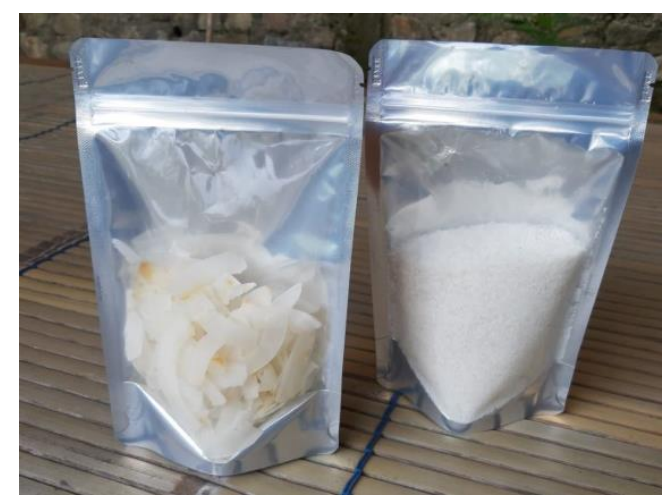

Gambar 7. Keripik kelapa yang dihasilkan oleh mitra 
Usai pemberian materi, dilakukan sesi diskusi. Pada sesi ini peserta cukup antusias menyampaikan berbagai pertanyaan terkait pemanfaatan dan pengolahan daging kelapa kepada tim. Peserta bahkan memiliki ide untuk membuat varian rasa pada keripik kelapa. Selain itu peserta juga menjadi tertarik dengan peluang usaha keripik kelapa. Setelah penyampaian materi yang disertai sesi diskusi maupun tanya jawab, peserta kembali diminta untuk mengisi kuisioner seperti ditunjukkan pada Gambar 8. Kuisioner tersebut ditujukan untuk mengetahui apakah kegiatan sosialisasi dan pengabidan kali ini mampu menambah wawasan dan pengetahuan mitra tentang pengolahan kelapa serta berbagai produk turunan dari kelapa.

Berdasarkan hasil kuisioner yang telah diisi oleh peserta, menunjukkan bahwa kegiatan sosialisasi pemanfaatan sekaligus pelatihan pengolahan kelapa menjadi keripik telah menambah pengalaman, wawasan dan keterampilan warga. Sebagian besar warga tertarik untuk mengolah kelapa menjadi berbagai produk yang bernilai ekonomi tinggi. Selain itu, peserta juga dapat menyebutkan berbagai varian produk olahan kelapa setelah mengikuti rangkaian kegiatan ini dan dapat mengurutkan tahapan pengolahan daging kelapa segar menjadi keripik kelapa.

\section{Tantangan Mitra}

Berdasarkan hasil kegiatan yang telah dilakukan, menunjukan bahwa pemahaman dan keterampilan mitra meningkat baik melalui sosialisasi maupun praktek pengolahan daging kelapa menjadi keripik kelapa. Namun demikian, beberapa tantangan yang dihadapi oleh peserta diantaranya adalah perlunya pemahaman mengenai cara pengolahan daging kelapa yang baik agar menjadi produk olahan yang tidak hanya bernilai ekonomi tinggi, tetapi juga aman dikonsumsi. Selain itu tantangan lainnya yaitu ketiadaan PIRT sehingga perlu adanya pembinaan dimasa mendatang mengenai cara pengajuan PIRT untuk produk keripik kelapa. Dengan adanya PIRT, dapat menjadi strategi pemasaran produk olahan daging kelapa agar jangkauan pemasarannya lebih luas dan mampu menjadi produk lokal unggulan bagi KUM Maju Bersama. Oleh karena itu diharapkan melalui serangkaian kegiatan yang telah dilaksanakan ini, setidaknya warga tertarik untuk mengolah daging kelapa menjadi keripik kelapa yang saat ini telah memiliki pasar sendiri dengan harga yang menjanjikan. Hal ini secara tidak langsung akan meningkatkan pendapatan anggota mitra.

\section{KESIMPULAN DAN SARAN}

\section{Kesimpulan}

Berdasarkan hasil kegiatan yang telah dialakukan diperoleh bahwa mitra belum mengenal keripik kelapa. Namun setelah mengikuti kegiatan ini, mitra mengetahui dengan baik manfaat dan produk olahan daging kelapa yang memiliki nilai ekonomi yang cukup tinggi. Selain itu, keterampilan mitra pun meningkat setelah melakukan praktek langsung pengolahan daging kelapa menjadi keripik kelapa. 
Saran

Perlu dilakukan tindak lanjut berupa pelatihan pengemasan dan penyimpanan keripik kelapa, serta pendampingan pengurusan PIRT keripik kelapa agar membantu strategi pemasaran dan memperluas jangkauan pemasaran.

\section{DAFTAR PUSTAKA}

Abadi, R. 2014. Diversifikasi Produk Buah Kelapa (Cocos nucifera L.) dalam http://kaltim.litbang.pertanian.go.i d/ind/pdf/divkelapa.pdf. Dikases 29 Februari 2020.
Kurniawan, H., Ansar, Yuniarto, K., Khalil, F.I. 2018. Introduksi Teknologi Pengemasan Gula Aren di Desa Kekait Kabupaten Lombok Barat. Widyabhakti Jurnal IImiah Populer, 1(1), 118-123

Subagio, A. 2011. Potensi Daging Buah Kelapa sebagai Bahan Baku Pangan Bernilai. PANGAN, Vol. 20(1): 1526

Wardanu, A. P., \& Anhar, M. 2014. Strategi Pengembangan Agroindustri Kelapa Sebagai Upaya Percepatan Ekonomi Masyarakat Di Kabupaten Ketapang. Jurnal Industria Vol 3 (1): 13-26. 